\title{
PENGARUH MOBILISASI DAN PENGGUNAAN VCO (VIRGIN COCONUT OIL) TERHADAP ULKUS DEKUBITUS PADA GANGGUAN FUNGSI MOTORIK PASCA STROKE
}

Jurnal Keperawatan dan Pemikiran IImiah

Setyawati, R (2015). Pengaruh Mobilisasi dan Penggunaan VCO (Virgin Coconut Oil) terhadap Ulkus Dekubitus pada Gangguan Fungsi Motorik Pasca Stroke. Nurscope. Jurnal Keperawatan dan Pemikiran IImiah. 1 (1). 1-7

\author{
Retno Setyawati ${ }^{1}$, Suyanto ${ }^{2}$, Mohammad Arifin Noor ${ }^{3}$ \\ ${ }^{1,2,3}$ Fakultas IImu Keperawatan' Universitas Islam Sultan Agung
}

\begin{abstract}
ABSTRAK
Ulkus dekubitus atau luka baring adalah tipe luka tekan, dan 7-8\% dinyatakan sebagai penyebab kematian pada paraplegia yang sering terjadi pada pasien stroke, sehingga perlu dilakukan tindakan perawatan yang tepat. Penelitian ini bertujuan Untuk mengetahui pengaruh mobilisasi dan penggunaan VCO (Virgin Coconut Oil) terhadap luka dekubitus pada gangguan fungsi motorik pasca stroke di Rumah Sakit Islam Sultan Agung Semarang. Desain penelitian quasi experiment, rancangan penelitian dengan menggunakan time series design dengan kelompok intervensi dan kontrol. Jumlah sampel 8 orang. Teknik pengambilan sampel purposive sampling. kelompok intervensi dilakukan mobilisasi 2-3 jam sekali dengan memberikan VCO sedangkan kelompok kontrol dilakukan mobilisasi lebih dari 2-3 jam sekali dan tidak diberikan VCO. Hasil penelitian menunjukkan bahwa tidak terdapat perbedaan grade dekubitus pada kelompok intervensi dan kontrol yang dilakukan mobilisasi dan diberikan VCO dengan nilai $p=0,495$. Perlunya tindakan yang tepat dilakukan pada pasien dengan gangguan fungsi motorik pasca stroke untuk mengurangi kejadian dekubitus.
\end{abstract}

Kata kunci: mobilisasi, VCO, ulkus decubitus, pasca stroke, gangguan fungsi motorik

MOBILIZATION AND VIRGIN COCONUT OIL (VCO) AS TREATMENT FOR PRESSURE ULCER IN STROKE PATIENTS

\section{ABSTRACT}

Pressure ulcer is often happened to patient has prolonged bed rest in hospital. Incidence of pressure ulcer increased every year especially in stroke patient. Nurses need to give proper treatment for stroke patient with motoric function disorder. This study aimed to explore the effect of mobilization and virgin coconut oil toward pressure ulcer in stroke patient at sultan agung islamic hospital. Time series design was used in this study. Utilized purposive sampling, the sample was divided in to control and intervention group with amount of 8 participants for each group. Intervention group was treat with mobilization for 2-3 hours added with VCO. Result of this study there is no significant different between mobilizations added with VCO or without VCO ( $p$ value $=0,495)$. Researchers suggest to do another proper treatment for stroke patient with motoric function disorder to decrease pressure ulcer.

Keywords: mobilization, VCO, pressure ulcer, post stroke, motoric function disorder

Corresponding Author :

Retno Setyawati ${ }^{1}$, Suyanto ${ }^{2}$, Mohammad Arifin Noor ${ }^{3}$, Departemen Keperawatan Medikal Bedah Fakultas IImu Keperawatan Universitas Islam Sultan Agung, Jalan Raya Kaligawe Km 4, Semarang, Jawa Tengah, Indonesia, Kode pos 50112

\section{PENDAHULUAN}

Klien stroke dengan gangguan mobilisasi beresiko tinggi terjadi dekubitus karena adanya penekanan pada bagian tubuh secara terus menerus akibat ketidakmampuan klien didalam mengubah posisi tubuh secara mandiri. Ulkus dekubitus atau luka baring adalah tipe luka tekan. Hal yang menjadi permasalahan adalah infeksi pada ulkus dekubitus termasuk sebagian infeksi nosokomial dan di Amerika Serikat menghabiskan dana sekitar satu miliar setiap tahun untuk pengobatannya. Penyakit ini sering terjadi pada klien dengan tirah baring lama di rumah sakit(Revis D.R, 2008). 
Prevalensi ulkus dekuitus pada Rumah Sakit sekitar 17-25\% dan dua dari tiga klien yang berusia 60 tahun atau lebih akan mengalami ulkus dekubitus. Di antara klien dengan kelainan neurologi, angka kejadian ulkus dekubitus setiap tahun sekitar 5-8\% dan ulkus dekubitus dinyatakan sebagai 7-8\% penyebab kematian pada paraplegia (Revis D.R, 2008).

Manajemen ulkus dekubitus dan keberhasilan penyembuhan harus memperhatikan beberapa prinsip yaitu: mengurangi tekanan (mobilisasi), debridemen, mengendalikan infeksi dan perawatan luka yang tepat. Penatalaksanaan yang biasa digunakan meliputi innovative mattresses, ointments, creams, solutions, dressings, ultrasonography, ultraviolet heat lamps, sugar, dan pembedahan (Kirman, 2015).

Mobilisasi dini yang seharusnya dilakukan pada klien stroke untuk menghindari dekubitus yaitu miring kiri dan kanan selang waktu 2-3 jam sekali, tetapi pada kenyataannya di ruang rawat inap ada yang melakukan mobilisasi dini dalam selang waktu lebih dari 4 jam dan pada akhirnya terjadi gangguan pada pasien diantaranya dekubitus (Morison, 2004).

Penatalaksanaan ulkus dekubitus dengan menggunakan prinsip menjaga kelembaban pada luka biasanya digunakan produk dengan berbasis minyak seperti creams, ointments, atau produk minyak asli seperti VCO. Virgin coconut oil (VCO) adalah minyak yang dihasilkan dari kelapa (Cocos nucifera L.) yang segar dan tua melalui proses mekanik dan alami, baik menggunakan pemanasan atau tidak hal tersebut tidak mempengaruhi transformasi pada minyak yang dihasilkan (APCC, 2003 dalam Mansor, T. S. T., Che Man, Y. B., Shuhaimi , M, Abdul Afiq, M. J. and Ku Nurul, 2012). VCO is found to contain a high amount of medium chain fatty acids such as lauric acid, caproic acid and caprylic acid. Studies found that medium chain fatty acids contain powerful antimicrobial properties

Hasil penelitian terdahulu tentang pengaruh mobilisasi pada klien stroke didapat $p$ value 0,525 pada kelompok kontrol penurunan grade dekubitus $2,8 \%$ pada kelompok eksperimen penurunan grade dekubitus 50\% ( $p$ value 0,0001), mobilisasi 2-3 jam sekali dapat menurunkan grade dekubitus (Yemima, 2007). Efek VCO terhadap dermatitis atopik diperoleh hasil bahwa VCO memiliki efek antibakterial terhadap kolonisasi Staphylococcusaureus pada pasien dermatitis atopik (Vermén M. Verallo-Rowell, Kristine M. Dillague, 2008). Penelitian mengenai pencegahan luka tekan melalui pijat menggunakan virgin coconut oil menunjukkan bahwa terdapat perbedaan yang bermakna terhadap kejadian luka tekan grade I antara responden yang diberikan perawatan pencegahan menggunakan VCO dengan pijat dan tanpa VCO setelah dikontrol oleh variabel Indeks Massa Tubuh (IMT) (Handayani, Irawaty, \& Panjaitan, 2011). Sebuah studi tentang pengaruh penggunaan coconut oil (Cocos nucifera L.) terhadap resiko ulkus dekubitus pada pasien bed rest menunjukkan hasil bahwa coconut oil dapat menurunkan resiko ulkus dekubitus pada pasien bed rest.(Dhikhil C D, 2014)

\section{HIPOTESIS}

Ada pengaruh antara mobilisasi dan penggunaan VCO (virgin coconut oil) terhadap ulkus dekubitus pada gangguan fungsi motorik pasca stroke. 


\section{METODE}

Penelitian ini menggunakan metode quasi experiment dengan pendekatan timeseriesdesign dengan jumlah sampel pada masing-masing kelompok adalah 8 orang. Adapun teknik pengambilan sampel yang digunakan yakni purposive sampling. Grade ulkus dekubitus dipastikan sama pada kedua kelompok, kemudian pada kelompok intervensi tindakan pemberian VCO dan mobilisasi per 2-3 jam. Sedangkan untuk kelompok kontrol hanya dilakukan mobilisasi lebih dari 2-3 jam. Pada kedua kelompok dilakukan intervensi selama 3 hari yang dilakukan pengukuran grade ulkus dekubitus setiap hari untuk mengamati perkembangan proses penyembuhan ulkus dekubitus yang dialami responden. Alat ukur yang digunakan untuk menilai proses penyembuhan ulkus dekubitus adalah Pressure Ulcer Scale for Healing(NPUAP, 1998)

\section{HASIL PENELITIAN}

Hasil penelitian tentang pengaruh penggunaan mobilisasi dan VCO terhadap luka dekubitus di ruang B. Izzah 2 Rumah Sakit Islam Sultan Agung Semarang. Penelitian ini dilakukan selama 4 minggu mulai tanggal 15 Januari 2012 sampai dengan tanggal 25 Februari 2012. Jumlah sampel yang didapatkan berdasarkan kriteria inklusi dan eksklusi sebanyak 8 responden. Dari jumlah tersebut dikelompokkan menjadi 2 kelompok yaitu 4 responden untuk kelompok intervensi dan 4 responden untuk kelompok kontrol. Berikut ini disajikan hasil penelitian :

a. Analisis Univariat

Tabel 1.1 Distribusi responden berdasarkan Jenis Kelamin

\begin{tabular}{lcccr}
\hline & Variabel & \multicolumn{2}{c}{ Kelompok intervensi } & \multicolumn{2}{c}{ Kelompok kontrol } \\
\cline { 2 - 5 } & $\mathrm{n}$ & $\%$ & $\mathrm{n}$ & $\%$ \\
\hline Jenis kelamin : & & & & 25 \\
a. laki-laki & 2 & 50 & 1 & 75 \\
b. perempuan & 2 & 50 & 3 & \\
\hline
\end{tabular}

Berdasarkan tabel 1.1 menunjukkan hasil bahwa distribusi jenis kelamin laki-laki dan perempuan pada kelompok intervensi sama besar yaitu masing-masing 50\% sedangkan pada kelompok kontrol sebagian besar berjenis kelamin perempuan yaitu $75 \%$.

Tabel 1.2 Distribusi responden berdasarkan Usia

\begin{tabular}{lcc}
\hline Variabel & $\begin{array}{c}\text { Min-Max } \\
\text { (Tahun) }\end{array}$ & $\begin{array}{c}\text { Mean } \\
\text { (Tahun) }\end{array}$ \\
\hline Usia & & 46 \\
a. Kelompok Intervensi & $40-50$ & 39.75 \\
b. Kelompok Kontrol & $35-46$ & 39 \\
\hline
\end{tabular}

Berdasarkan tabel 1.2 menunjukkan hasil bahwa distribusi usia pada kelompok intervensi ratarata 46 tahun dengan rentang usia termuda 40 tahun dan tertua 50 tahun sedangkan pada 
kelompok kontrol sebagian rata-rata 39.75 tahun dengan rentang usia termuda 35 tahun dan tertua 46 tahun.

b. Analisa bivariat

Tabel 4.1. Perbedaan kejadian dekubitus pada kelompok kontol dan intervensi di Ruang

B.Izzah 2 RS.Islam Sultan Agung Semarang 2012

\begin{tabular}{|c|c|c|c|}
\hline & \multicolumn{3}{|c|}{$(n=8)$} \\
\hline & \multirow[b]{2}{*}{ Variabel } & Mann Whitney & \multirow[t]{2}{*}{$p$ Value } \\
\hline & & Mean & \\
\hline Pair 1 & Kontrol-Intervensi & $4.00-5.00$ & .495 \\
\hline
\end{tabular}

Berdasarkan tabel di atas diperoleh nilai $\mathrm{p}=0,495(>0.05)$, maka dapat disimpulkan pada alpha $5 \%$ bahwa tidak terdapat perbedaan yang signifikan luka dekubitus pada pemberian mobilisasi dan penggunaan VCO pasien dengan gangguan fungsi motorik pasca stroke.

\section{DISKUSI}

Penelitian ini menunjukkan bahwa tidak terdapat perbedaan luka dekubitus pada kelompok intervensi dan kelompok kontrol dengan pemberian mobilisasi dan penggunaan VCO dengan nilai $p=$ 0,495. Hasil ini tidak sesuai dengan sebuah studi yang dilakukan oleh Yemima (2007) yang menyatakan bahwa ada pengaruh yang signifikan pada pemberian mobilisasi terhadap penurunan grade decubitus.

Grade dekubitusdan tekanan serta kekuatan gesekan akan mengganggu mikrosirkulasi jaringan lokal, dan mengakibatkan hipoksia serta memperbesar pembuangan metabolik yang dapat menyebabkan nekrosis. Hampir semua dekubitus terutama disebabkan oleh tekanan yang terus menerus. Biasanya terjadi pada pasien yang mengalami immobilisasi (Mulyatsih, 1994)

Kelompok intervensi dilakukan mobilisasi per 3 jam dan penggunaan VCO selama 3 hari. Penggunaan VCO dilakukan sehari 2 kali yakni setelah mandi pagi dan sore, dengan dioleskan pada area punggung sambil dilakukan masase. Sedangkan pada kelompok kontrol hanya dilakukan mobilisasi selama 3 hari tanpa penggunaan VCO dengan pergantian posisi per 3 jam. Sumbatan total pada kapiler masih bersifat reversible bila kurang dari 2 jam. Seorang yang terpaksa berbaring berminggu-minggu tidak akan mengalami ulkus dekubitus selama dapat mengganti posisi beberapa kali perjamnya.(Hidayat, Djunadi, Daili S.F, 1999; Pendland, Susan L., 2005; Wilhelmi, 2008)

Virgin Coconut Oil atau minyak kelapa murni terbuat dari daging kelapa segar. Riset dan uji klinis telah membuktikan keampuhan dan khasiat virgin coconut oil untuk menyembuhkan berbagai penyakit dan kehidupan sehat lainnya.

Keterbatasan penelitian meliputi: sampel, dalam penelitian ini hanya melibatkan total 8 responden yang dibagi kedalam 2 kelompok intervensi dan control masing-masing 4 responden sehingga belum 
bisa dijadikan sebagai acuan untuk menggeneralisasikan hasil penelitian ini. Belum dilakukan uji homogenitas untuk mengetahui kesetaraan antara kelompok intervensi dan kelompok kontrol.

\section{SIMPULAN}

Berdasarkan hasil penelitian dan pembahasan yang telah diuraikan sebelumnya, maka simpulan yang dapat diambil dari penelitian ini didapatkan hasil bahwa nilai $p$ value $=0.495$, sehingga dapat disimpulkan pada tingkat significancy $5 \%$ tidak didapatkan perbedaan yang signifikan antara mobilisasi dan pengguanaan VCO terhadap luka dekubitus pada pasien dengan gangguan fungsi motorik pasca stroke.

Saran yang direkomendasikan bahwa perawat perlu memahami berbagai teknik penanganan pasien dengan gangguan fungsi motorik pasca stroke untuk mengantisipasi terjadinya luka dekubitus atau menurunkan grade dekubitus jika telah terjadi luka. Institusi pendidikan dan pelayanan kesehatan dapat memfasilitasi perawat untuk pengembangan diri guna meningkatkan pengetahuan dan keterampilan terkait perawatan pada pasien dengan gangguan fungsi motorik.

\section{DAFTAR PUSTAKA}

Dhikhil C D, K. M. L. and L. E. V. (2014). Effect of coconut oil usage in risk of pressure ulcers among bedridden patients of selected hospitals in North India. iP-Planet,1,71-78. Retrievedfromipharmacyplanet.com/.../50_5_iPPlanet13N.pdf

Handayani, R. S., Irawaty, D., \& Panjaitan, R. U. (2011). Pencegahan Luka Tekan melalui Pijat $\begin{array}{lllll}\text { menggunakan Virgin } & \text { Coconut } & \text { Oil. } & \text { Retrieved }\end{array}$ jki.ui.ac.id/index.php/jki/article/viewFile/60/pdf

Hidayat, Djunadi, Daili S.F, dan H. M. (1999). Ulkus Dekubitus Dalam Cermin Dunia Kedokteran. Retrieved April 11, 2011, from www.kalbe.co.id

Kirman, C. N. (2015). Pressure Ulcers and Wound Care Treatment \& Management. Retrieved from http://emedicine.medscape.com/article/190115-treatment\#showall

Mansor, T. S. T., Che Man, Y. B., Shuhaimi , M, Abdul Afiq, M. J. and Ku Nurul, F. K. M. (2012). Physicochemical properties of virgin coconut oil extracted from different processing methods. International Food Research Journal, 19, 837-845.

Morison, M. J. (2004). A Colour Guide to the Nursing Management of Wounds. Jakarta : EGC.

Mulyatsih, E. (1994). Stroke, Petunjuk Praktis bagi Pengasuh dan Keluarga Klien Pasca Stroke. Jakarta: FKUI.

NPUAP, N. P. U. A. P. (1998). Pressure Ulcer Scale for Healing Tool (PUSH Tool). Retrieved from http://www.npuap.org/wp-content/uploads/2012/03/push3.pdf

Pendland, Susan L., et al. (2005). Skin and Soft Tissue Infection. Chicago:McGrawHill.

Revis D.R. (2008). Decubitus Ulcer. Retrieved April 11, 2011, from www.emedicine.com

Vermén M. Verallo-Rowell, Kristine M. Dillague, B. S. S.-T. (2008). Novel Antibacterial and Emollient Effects of Coconut and Virgin Olive Oils in Adult Atopic Dermatitis. American Contact Dermatitis Society, 19, 308-315. Retrieved from www.ncbi.nlm.nih.gov/pubmed/19134433

Wilhelmi, B. J. (2008). Pressure Ulcer, Surgical Treatment and Principles.No Title. Retrieved from 
www.emedicine.com

Yemima. (2007). Pengaruh Mobilisasi Pada Klien Stroke Yang Mengalami Gangguan Fungsi Motorik Dengan Kejadian Dekubitus Di Rumah Sakit Mardi Rahayu Kudus. UNDIP (tidak dipublikasi). 